Klein, M., and Kalter, S. S. (1946). J. Bact., 51, 95.

Kand Kimmelman, L. J. (1947). Ibid., 54, 363.

Knapp, W. (1950). Z. Hyg. InfektKr., 131, 259.

Kolmer, J. A. (1948). Amer. J. med. Scl., 215, 136.

Lankford, C. E., and Lacy, Helen (1949). Tex. Rep. Biol. Med., 7, 111.

Lepper, M. H., and Dowling, H. F. (1951). Arch. intern. Med., 88, 489.

(1952). J. Lab. clin. Med., 40, 891., Spies, H. W., and Brown, M.

Martin, R., Chabbert. Y., and Sureau, B. (1953). Presse méd. In press.

Sureau, B., and Chabbert, Y. (1952). Bull. Soc. Méd., Paris, 68, 1192

Nitti, F., Boyer, F., and Faguet, M. (1946). Ann. Inst. Pasteur, 72, 687.

Peyré, M., and Velu, H. (1952). Rev. Immunol., 16, 142.

Price, C. W., Randall, W. A., Welch, H., and Chandler, Velma L. (1949). Amer. J. publ. Hith, 39, 340.

Reid. J. D., Jones, Muriel M., and Bryce, Evelyn C. (1952). Antibiot. and Chemother., 2, 351.

Report (1949). British Medical Journal, 2, 1521.

- (1953). Ibid., 1, 521.

Richter, J. (1952). Z. Hyg. InfektKr., 134, 549.

Robbins, W. C., and Tompsett, R. (1951). Amer. J. Med., 10, 278.

Scowen, E. F., and Garrod, L. P. (1948). British Medical Journal, 2, 1099

Smith, Honor V., Duthie, E. S., and Cairns, H. (1946). Lancet, 1, 185.

Soo-Hoo, G., and Schnitzer, R. J. (1944). Arch. Biochem., 5, 99.

Speck, R. S., and Jawetz, E. (1952). Amer. J. med. Sci. 223, 280

Spies, H. W., Dowling, H. F., Lepper, M. H., Wolfe, C. K., and Caldwell, E. R. (1951). Arch. intern. Med., 87, 66.

Spink, W. W. Hall, W. H., Shaffer, J. M., and Braude, A. I. (1948). J. Amer. med. Ass., 136, 382

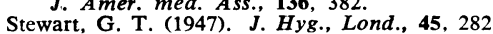

Thomas, J. C., and Hayes, W. (1947). Ibid., 45, 313.

Ungar, J. (1943). Nature, Lond., 152, 245.

Waring, A. J., and Smith. Margaret H. D. (1944). J. Amer. med. Ass., 126, 418 .

\section{CLINICAL TRIAL OF A NEW ORAL DIURETIC}

\author{
BY
}

A. G. SPENCER, M.D., M.R.C.P.

Assistant, Medical Unit,

University College Hospital Medical School, London

AND

H. G. LLOYD-THOMAS, M.B., B.Chir., M.R.C.P. Assistant Registrar, University College Hospital, London

In a search for a potent non-toxic oral diuretic, Kattus, Newman, and Franklin (1951) tested for diuretic activity in dogs a series of compounds derived from the uracil nucleus. One compound, 1-propyl-3-ethyl-6-aminouracil, was found to be an effective diuretic, and produced only a minor degree of gastro-intestinal disturbance. Papesch and Schroeder (1950) had previously synthesized this substance, and for convenience it is referred to by their serial number, S.C.2614. The structural formula is :<smiles>CCCn1c(N)cc(=O)n(CC)c1=O</smiles>

Kattus, Arrington, and Newman (1952) subsequently reported that compound S.C.2614 was an effective diuretic when given by mouth to dogs, to normal human subjects, and to patients with oedema. No serious toxic reactions were noted in their studies.

The present report describes an investigation into the effectiveness of compound S.C.2614 as an oral diuretic when given to normal human subjects and to patients with renal or cardiac disease.

Chemical Methods.-The daily renal excretion of protein was determined by micro-Kjeldahl estimation of the protein precipitate obtained from centrifuged aliquots of the 24-hour urine. The other chemical methods have been described previously (Spencer and Franglen, 1952).

\section{Effect on Normal Subjects}

Observations on the diuretic effect of S.C.2614 were made during ten tests on nine normal males aged 21-35 years.
These subjects were ambulant and took their normal diet. Urine was collected over two 24-hour periods; the first period being the control day, and the second the test day on which $1,250 \mathrm{mg}$. of S.C.2614 was taken by mouth in 125-mg. tablets over a period of six hours. The renal excretion of water, sodium, chloride, and potassium was measured on each day, and the results are summarized in Tables I and II.

TABLE I.-Effect of Compound S.C.2614 on Normal Subjects. The 24-hour Renal Excretion of Water and Sodium on a Control Day Compared with that on a Day when 1,250 mg. of S.C.2614 was Taken by Mouth. Ten Tests on Normal Subjects

\begin{tabular}{|c|c|c|c|c|c|}
\hline \multirow{3}{*}{ Subject } & & \multicolumn{4}{|c|}{ Renal Excretion in 24 Hours } \\
\hline & & \multicolumn{2}{|c|}{ Water (ml.) } & \multicolumn{2}{|c|}{ Sodium (mEq) } \\
\hline & & Control & S.C. 2614 & Control & S.C. 2614 \\
\hline $\begin{array}{l}\text { G.A..' } \\
\text { T.R.B. } \\
\text { G.C. } \\
\text { A.M.G. } \\
\text { A.B.K. } \\
\text { M.N. } \\
\text { G.M. } \\
\text { A.G.S. } \\
\text { A.G.S. } \\
\text { L.T. . . }\end{array}$ & $\begin{array}{l}\cdots \\
\cdots \\
\cdots \\
\cdots \\
\cdots \\
\cdots \\
\cdots\end{array}$ & $\begin{array}{r}800 \\
2,150 \\
1,210 \\
1,730 \\
2,355 \\
1,545 \\
1,390 \\
1,470 \\
1,479 \\
1,600\end{array}$ & $\begin{array}{l}2,320 \\
3,140 \\
1,430 \\
2,630 \\
3,620 \\
2,410 \\
2,230 \\
2,930 \\
2,640 \\
2,960\end{array}$ & $\begin{array}{r}152 \\
110 \\
179 \\
157 \\
167 \\
154 \\
159 \\
99 \\
158 \\
196\end{array}$ & $\begin{array}{l}260 \\
251 \\
320 \\
330 \\
375 \\
384 \\
210 \\
303 \\
457 \\
525 .\end{array}$ \\
\hline
\end{tabular}

TABLE II-Effect of Compound S.C.2614 on Normal Subjects. The 24-hour Renal Excretion of Water and Sodium on Control Day Compared with that on a Day when 1,250 mg. of S.C.2614 was Taken by Mouth. Means and Standard Deviations of the Data from Ten Tests on Nine Normal Subjects

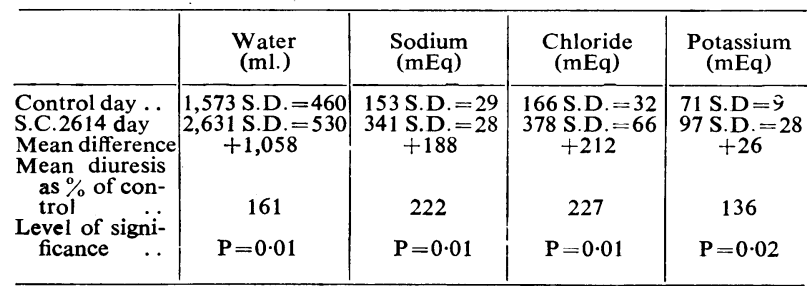

In nine of the ten tests there was a considerable increase in the urine volume and excretion of sodium and chloride on the test day. One subject did not show a significant water diuresis, although his excretion of sodium on the test day was $178 \%$ of that on the control day. For all the ten tests the mean excretions on the test day compared with the control day were: water, $161 \%$; sodium, $222 \%$; chloride, $227 \%$; potassium $136 \%$. In these tests the water diuresis in response to oral S.C.2614 was equivalent to that reported by Blumgart et al. (1934) for mercurial diuretics when given by intramuscular injection to normal subjects. The effect of oral S.C.2614 on sodium excretion also compared favourably with that reported by Kattus et al. (1952) for a $2-\mathrm{ml}$. injection of a mercurial diuretic in a comparable series of normal subjects, and was much greater than that which was produced by $1.2 \mathrm{~g}$. of aminophylline by mouth.

Toxic Reactions.-Two subjects complained of epigastric pain and abdominal discomfort, one of anorexia, and two of tinnitus. During the administration of S.C.2614 there was no significant change in the low normal rate of daily excretion of protein in the urine, and in no case did urine microscopy show any abnormality.

\section{Effect on Patients : Method of Investigation}

The patients were not deliberately selected, and included those with every degree of fluid retention, from little or no pitting oedema to gross anasarca. Fifty tests were completed on 30 patients, 22 with cardiovascular and 8 with renal disease. All patients were confined to bed and, except when otherwise stated, were given a standard hospital lowsalt diet $(10-25 \mathrm{mEq})$ of sodium and a measured fluid intake of $30-50 \mathrm{oz}$. $(850-1,420 \mathrm{ml}$.). There was a preliminary period of observation of at least six days in which to 
detect and exclude those patients who were undergoing a spontaneous diuresis in response to rest in bed and the low-salt diet. Patients treated with digitalis were observed for a longer period, usually one to three weeks, so as to avoid confusion with the diuretic effect of this drug.

TABle III.-Effect of Oral S.C.2614 on Patients with Cardiovascular or Renal Disease

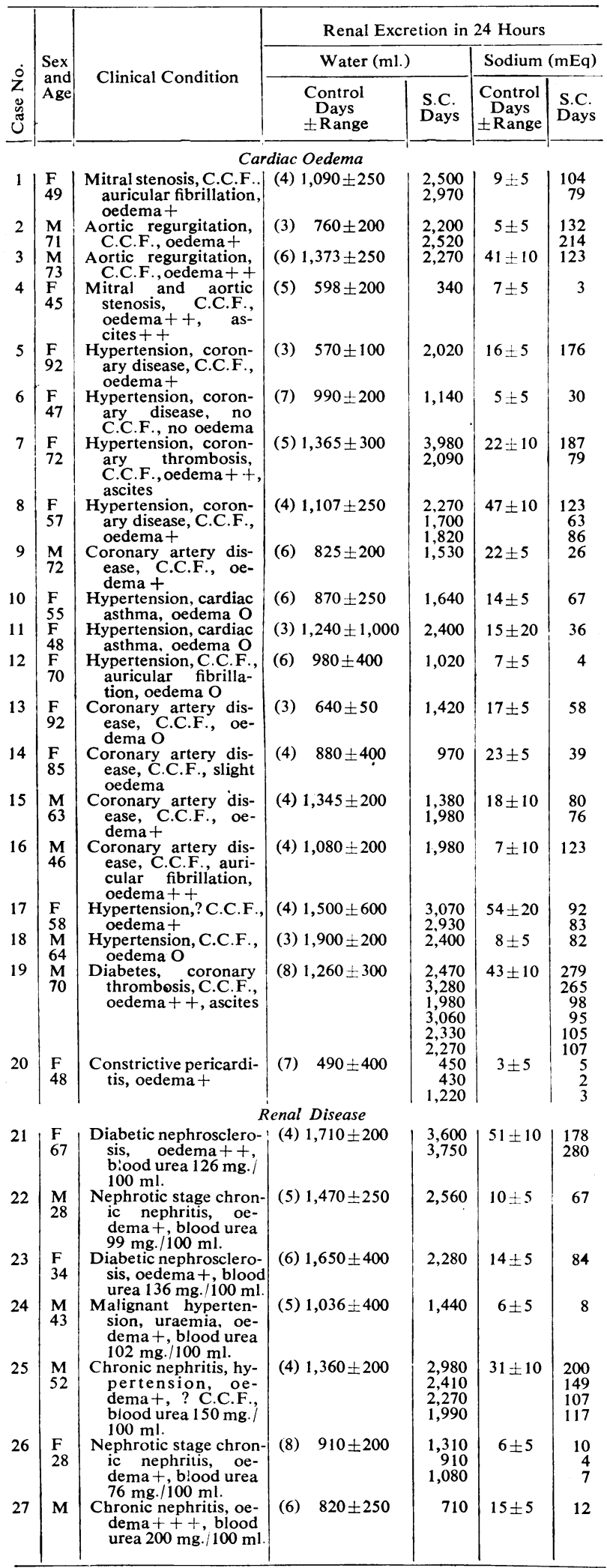

The daily renal excretion of water, sodium, potassium, and chloride ions was measured for three to eight days before the test, on the test day, and for a variable time afterwards. On the test day, starting at 9 a.m., compound S.C. 2614 was given by mouth in $125-\mathrm{mg}$. tablets, two every three hours until $1,250 \mathrm{mg}$. had been taken. The deposits from the centrifuged urine were examined microscopically in the control period and on the test day. The 24-hour excretion of protein in the urine of 26 patients was also measured.

An approximate comparison of the effectiveness of oral S.C.2614 with a 2-ml. intramuscular injection of mersalyl B.P. was obtained by testing both diuretics in 22 patients. There was an interval of at least four days between the two tests, and nine of the patients received the mersalyl injection before the S.C.2614 tablets, while the others were given the S.C.2614 tablets first.

Two tests were invalidated by errors in urine collection, and three patients were given a diet containing approximately $40 \mathrm{mEq}$ of sodium a day, instead of the standard diet containing $10-25 \mathrm{mEq}$ of sodium. The main results of 47 tests, together with a summary of the clinical condition of the patients, are given in Table III.

\section{Assessment of Diuresis}

There were formidable difficulties in the assessment of a diuretic response. The test patients differed in the nature of their disease, in the causation of their oedema, in renal function, and in many other variable factors important in the differential distribution of body fluids, such as the concentration of the serum albumin and that of the plasma sodium. Not only did the patients necessarily differ among themselves but there was a considerable variation from day to day in the same patient of the renal excretion of water and electrolytes. This was still the case when the input was constant within the limits of a standard low-salt diet. The prolonged period of observation, necessary to detect and exclude those patients undergoing a diuresis in response to rest and other forms of treatment, produced two further difficulties. First, many patients lost their pitting oedema before the test ; and, secondly, the remaining patients with oedema were no longer a representative series, and in fact many were particularly resistant to all forms of treatment. This selection of patients reduced the chance of a successful diuresis in response to compound S.C.2614; but when such a diuresis occurred it could be attributed with more confidence to the drug.

A successful diuretic response has been defined as one in which all the following standards were exceeded on the test day: a urine volume of $70 \mathrm{oz}$. $(1,990 \mathrm{ml}$.) containing $75 \mathrm{mEq}$ sodium; an excess renal excretion over the intake of $30 \mathrm{oz}$. $(850 \mathrm{ml}$.) of water and $50 \mathrm{mEq}$ sodium; an excretion of $150 \%$ of the mean control values for both water and sodium, with increments greater than four times the mean deviations.

\section{Results in Patients with Heart Disease}

Thirty-four tests were completed on 20 patients with heart disease: four with chronic rheumatic carditis and valvular disease, one with constrictive pericarditis, and fifteen with hypertension or disease of the coronary arteries (Table III). The mean results for all the tests on cardiac patients are given in Table IV.

However, these average figures do not represent the true clinical response to compound S.C.2614. The data are abnormally distributed within the series, so that the average figures are misleading. On applying the strict criteria of a

TABLE IV

\begin{tabular}{c|c|c|c|c|c}
\hline \multirow{2}{*}{$\begin{array}{c}\text { No. of } \\
\text { Patients }\end{array}$} & $\begin{array}{c}\text { No. of } \\
\text { Tests }\end{array}$ & \multicolumn{2}{|c|}{ Water Excretion } & \multicolumn{2}{c}{ Sodium Excretion } \\
\cline { 3 - 6 } \cline { 3 - 5 } & $\begin{array}{c}\text { Mean } \\
\text { Control }\end{array}$ & $\begin{array}{c}\text { Mean } \\
\text { S.C.2614 }\end{array}$ & $\begin{array}{c}\text { Mean } \\
\text { Control }\end{array}$ & $\begin{array}{c}\text { Mean } \\
\text { S.C.2614 }\end{array}$ \\
\hline 20 & 34 & $1,045 \mathrm{ml}$. & $2,040 \mathrm{ml}$. & $27 \mathrm{mEq}$ & $92 \mathrm{mEq}$ \\
\hline
\end{tabular}


TABLE V

\begin{tabular}{|c|c|c|c|c|c|c|}
\hline \multirow{2}{*}{$\begin{array}{l}\text { No. of } \\
\text { Patients }\end{array}$} & \multirow{2}{*}{$\begin{array}{l}\text { No. of } \\
\text { Tests }\end{array}$} & \multirow{2}{*}{$\begin{array}{c}\text { Successful } \\
\text { Diuresis }\end{array}$} & \multicolumn{2}{|c|}{ Water Excretion } & \multicolumn{2}{|c|}{ Sodium Excretion } \\
\hline & & & $\begin{array}{l}\text { Mean } \\
\text { Control }\end{array}$ & $\begin{array}{c}\text { Mean } \\
\text { SC.2614 }\end{array}$ & $\begin{array}{l}\text { Mean } \\
\text { Control }\end{array}$ & $\begin{array}{l}\text { Mean } \\
\text { S.C. } 2614\end{array}$ \\
\hline 10 & 22 & 19 & $1,070 \mathrm{ml}$. & $2.530 \mathrm{ml}$. & $23 \mathrm{mEq}$ & $121 \mathrm{mEq}$ \\
\hline
\end{tabular}

successful diuretic response which we have previously defined, it is apparent that of the 34 tests 20 were successful; but these 20 successful tests occurred in only 10 patients. This series has therefore been subdivided into three groups:

(a) Oedematous Patients Without Evidence of Sodium Depletion (Table V).-The diuretic response to S.C.2614 in this group of patients was very satisfactory, and, as will be shown later, the results were comparable with those obtained from intramuscular mersalyl. An example of a successful series of diuretic responses is given in the accompanying Chart.

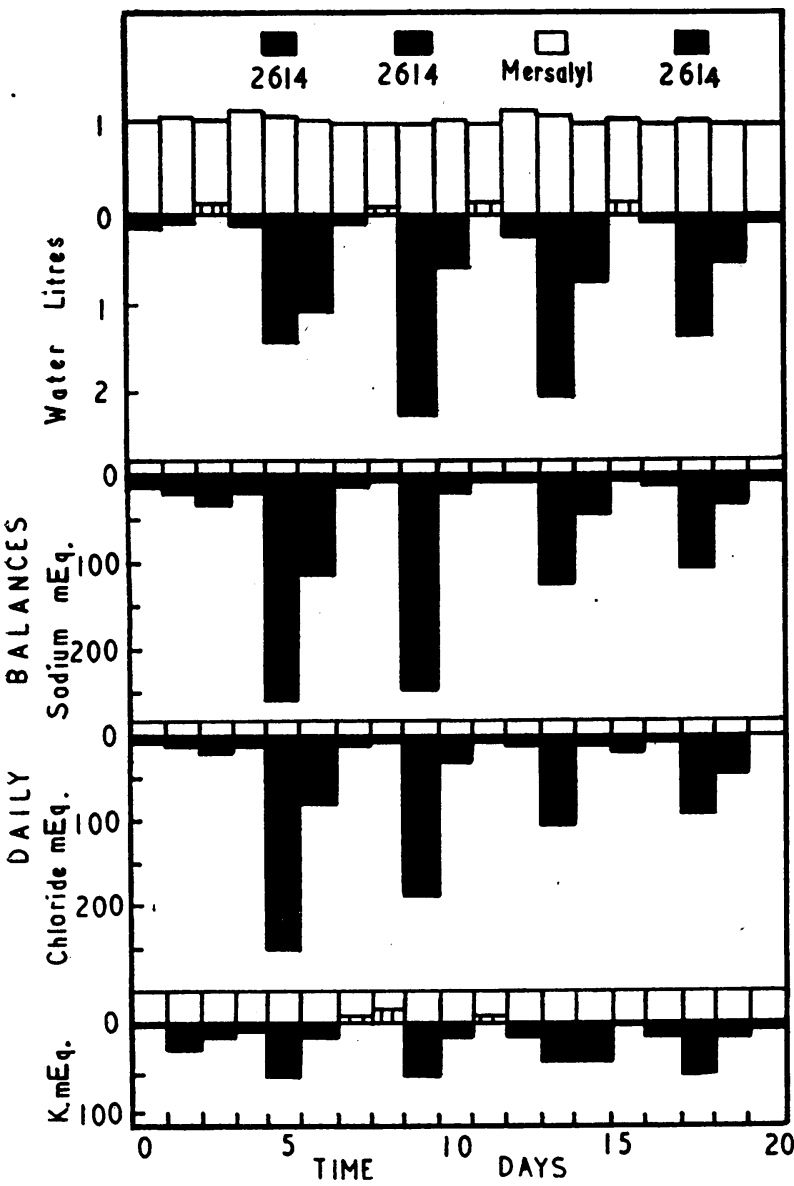

The effect of oral S.C.2614 and of intramuscular mersalyl $(2 \mathrm{ml}$.) on an oedematous patient with congestive cardiac failure. The daily balances of water, sodium, potassium, and chloride ions. Intake $20 \mathrm{mEq}$ sodium and $1,000-1,200 \mathrm{ml}$. of water a day. Input plotted upwards from the base lines and output downwards from the level of the input, so that the black columns represent the daily negative balances.

(b) Oedematous Patients with Sodium Depletion. (Plasma sodium below $132 \mathrm{mEq}$, or a recent large abdominal paracentesis.) (Table VI).-There was no successful diuretic

TABLE VI

\begin{tabular}{c|c|c|c|c|c|c}
\hline $\begin{array}{c}\text { No. of } \\
\text { Patients }\end{array}$ & \multirow{2}{*}{$\begin{array}{c}\text { No. of } \\
\text { Tests }\end{array}$} & Failures & \multicolumn{2}{|c|}{ Water Excretion } & \multicolumn{2}{|c|}{ Sodium Excretion } \\
\cline { 2 - 6 } & $\begin{array}{c}\text { Mean } \\
\text { Control }\end{array}$ & $\begin{array}{c}\text { Mean } \\
\text { S.C.2614 }\end{array}$ & $\begin{array}{c}\text { Mean } \\
\text { Control }\end{array}$ & $\begin{array}{c}\text { Mean } \\
\text { S.C.2614 }\end{array}$ \\
\hline 2 & 4 & 4 & $540 \mathrm{ml}$. & $605 \mathrm{ml}$. & $5 \mathrm{mEq}$ & $3 \mathrm{mEq}$ \\
\hline
\end{tabular}

response in this small group of patients. One subsequently had a good diuresis following an injection of mersalyl.

(c) Patients Without Pitting Oedema (Table VII).Although none of this group of patients had a good diuresis in response to oral S.C.2614, there was a noticeable effect on water and sodium excretion. This was approximately half of that obtained in those patients with oedema and no evidence of sodium depletion.

\section{TABLE VII}

\begin{tabular}{c|c|c|c|c|c|c}
\hline $\begin{array}{c}\text { No. of } \\
\text { Patients }\end{array}$ & $\begin{array}{c}\text { No. of } \\
\text { Tests }\end{array}$ & Failures & \multicolumn{2}{|c|}{ Water Excretion } & \multicolumn{2}{|c}{ Sodium Excretion } \\
\cline { 4 - 7 } & $\begin{array}{c}\text { Mean } \\
\text { Control }\end{array}$ & $\begin{array}{c}\text { Mean } \\
\text { S.C.2614 }\end{array}$ & $\begin{array}{c}\text { Mean } \\
\text { Control }\end{array}$ & $\begin{array}{c}\text { Mean } \\
\text { S.C.2614 }\end{array}$ \\
\hline 8 & 8 & 8 & $992 \mathrm{ml}$. & $1,537 \mathrm{ml}$ & $13 \mathrm{mEq}$ & $53 \mathrm{mEq}$ \\
\hline
\end{tabular}

\section{Comparative Efficiency of Oral S.C.2614 with Intramuscular Mersalyl}

Because patients differed widely in their response to a single diuretic, and as the response of the same patient also varied from day to day, it was extremely difficult to obtain a reliable comparison of the relative effectiveness of two different diuretics. In the twin tests of oral S.C.2614 and intramuscular mersalyl $(2 \mathrm{ml}$.) the order in which the diuretics were tested obviously affected the result (Table VIII).

TABLE VIII.-Efficiency of Oral S.C.2614 Compared with a 2-ml. Intramuscular Injection of Mersalyl in Patients with. Cardiac Disease

\begin{tabular}{|c|c|c|c|c|c|c|c|}
\hline & \multirow{2}{*}{$\begin{array}{l}\text { No. } \\
\text { of } \\
\text { Tests }\end{array}$} & \multicolumn{3}{|c|}{ S.C. 2614 Mean Diuresis } & \multicolumn{3}{|c|}{ Mersalyl Mean Diuresis } \\
\hline & & $\begin{array}{l}\text { Water } \\
\text { (ml.) }\end{array}$ & $\underset{(\mathrm{mEq})}{\text { Sodium }}$ & Successes & $\begin{array}{l}\text { Water } \\
\text { (ml.) }\end{array}$ & $\underset{(\mathrm{mEq})}{\text { Sodium }}$ & Successes \\
\hline $\begin{array}{l}\text { Mersalyl } \\
\text { first. } \\
\text { S.C. } 2614\end{array}$ & 9 & 1,760 & 43 & 4 & 2,353 & 97 & 8 \\
\hline first. . & 13 & 2,146 & 81 & 8 & 2,173 & 63 & 5 \\
\hline
\end{tabular}

When mersalyl was given first it produced twice as many successful diuretic responses as did the subsequent tests of S.C.2614, and the mean excretion of water and of sodium in response to mersalyl was much greater. When compound S.C.2614 was tested first it produced eight successful diuretic responses compared with five by mersalyl, but the mean excretion of water and sodium was of the same order for both diuretics. For both groups of tests the mean excretion of water and of sodium was, for mersalyl $2,260 \mathrm{ml}$. of water and $80 \mathrm{mEq}$ of sodium; for S.C.2614 $1,950 \mathrm{ml}$. of water and $62 \mathrm{mEq}$ of sodium. It appeared, therefore, that although compound S.C.2614 was an effective diuretic in the oedematous patients it was not generally such a potent diuretic as a 2-ml. intramuscular injection of mersalyl.

This conclusion is supported by a comparison of the data available for compound S.C.2614 with those published for mercurial diuretics in patients with heart disease (Table IX). The approximate relative efficiency of various diuretics compared with intramuscular mercurials $(100 \%)$ appears to be : intravenous mersalyl, $120-140 \%$; mersalyl suppositories, $40 \%$; "novurit" suppositories, $80 \%$; oral "unephral"

TABLE IX.-A Comparison of the Response to Various Diuretics in Patients with Heart Disease. Urine Volumes $(\mathrm{ml}$.$) on the$ Test Day

\begin{tabular}{l|c|c|c|c}
\hline $\begin{array}{c}\text { Oral } \\
\text { S.C.2614 }\end{array}$ & $\begin{array}{c}\text { Oral } \\
\text { Mercurials }\end{array}$ & $\begin{array}{c}\text { Mercurial } \\
\text { Suppository }\end{array}$ & $\begin{array}{c}\text { Intramuscular } \\
\text { Mercurials }\end{array}$ & $\begin{array}{c}\text { Intravenous } \\
\text { Mersalyl }\end{array}$ \\
\hline 1,9601 & $\begin{array}{c}\text { Mersalyl 1,5003 } \\
\text { Unephral 1,8763 }\end{array}$ & $\begin{array}{c}1,3508 \\
2,3604 \\
(\text { novurit) }\end{array}$ & 2,1904 & 3,0003 \\
$2,5302 \mathrm{a}$ & $* 6003$ & 2,8604 \\
$* 70-110 \%$ & $* 60-70 \%$ & $* 40-80 \%$ & $* 100 \%$ & $* 120-140 \%$ \\
\hline
\end{tabular}

1 Kattus et al. (1952) all cases. Calculated from Evans and Paxton. 2 Present series, all cases. (1941).

2a Present series, oedematous cases. 4 Thomson (1937).

* Approximate efficiency compared with intramuscular mercurial diuretics used with theophylline and ammonium chloride. 
(formerly " neptal"), 70\%; oral mersalyl, 60\% ; oral S.C.2614, 70-110\%. The mercurial diuretics contained theophylline and were given in conjunction with ammonium chloride.

\section{Results in Patients with Renal Disease}

There were 13 tests of compound S.C.2614 on seven patients, and in only two was there a successful diuretic response (Table III). Two successful responses were obtained from a patient with diabetic nephrosclerosis, and four from a patient with chronic nephritis, but the oedema in the latter case was probably produced in part by congestive heart failure.

\section{Toxic Reactions to Oral Compound S.C.2614}

Gastro-intestinal disturbances were reported by 9 of the 39 subjects who were given compound S.C.2614. The complaints were: epigastric discomfort, 9 ; anorexia, 8 ; nausea, 7 ; vomiting, 4. Apart from the four patients who each vomited on a single occasion, the symptoms were mild and did not interfere with the administration of the tablets.

Two normal subjects complained of tinnitus. One patient had a transient sparse urticarial eruption.

Routine microscopy of the urine did not show any alteration in the pattern of the organized deposit following the administration of S.C.2614.

Patients with gross albuminuria often showed a pronounced increase in the 24-hour excretion of urinary protein on the day in which S.C.2614 was given.

\section{Comment}

The therapeutic value of a new drug, and its toxic effects, can be assessed only by a prolonged study of its action on a large number of patients. Such a large-scale clinical trial would be justified by the unqualified success of the drug in a pilot experiment. The present trial of S.C.2614 appeared to show that, in a divided dose of $1.25 \mathrm{~g}$., it was an effective oral diuretic in $70 \%$ of patients with cardiovascular disease, provided there was definite oedema and no evidence of sodium depletion. In this group of patients oral S.C.2614 was usually about $80 \%$ as effective as a $2-\mathrm{ml}$. intramuscular injection of mersalyl, preceded by ammonium chloride. There was seldom a useful diuretic response to S.C.2614 in the absence of oedema or in patients who had a low plasma sodium, a serum albumin below $2 \mathrm{~g}$. per $100 \mathrm{ml}$., or a blood urea over $150 \mathrm{mg}$. per $100 \mathrm{ml}$. Intramuscular mersalyl was also generally less effective in these patients, but usually more successful than S.C.2614. There was not enough evidence to assess the value of S.C.2614 in patients with renal disease, but there were some good diuretic responses.

This useful diuretic action of S.C.2614 was seriously offset by the high incidence of gastro-intestinal disturbance following the ingestion of the tablets. Although these symptoms were rarely severe, they were sufficient to elicit a spontaneous complaint from $23 \%$ of the test subjects. We have therefore begun a pilot trial of a related aminouracil compound which is believed to be less toxic that compound S.C.2614 (Winter, personal communication). For these reasons it is thought that extensive trials of compound S.C.2614 are not justified at the present time.

An effective non-toxic diuretic would undoubtedly be useful in domiciliary practice and when the mercurial diuretics are contraindicated. Further studies of the aminouracil compounds may therefore be profitable, either by themselves or in conjunction with other diuretics.

\section{Summary}

A new oral diuretic, an aminouracil compound designated S.C.2614, was tested 57 times in 36 subjects in a divided dosage of $1.25 \mathrm{~g}$.

In normal subjects there was a satisfactory diuresis in nine out of ten tests. Expressed in relation to the mean excretion on the control days the mean diuresis was : of water, $161 \%$; sodium, $222 \%$; chloride, $227 \%$; and potassium, $136 \%$.

In 22 tests on 10 oedematous patients with heart disease there was a good diuretic response in 19, with a mean urine volume of $2,530 \mathrm{ml}$. containing $121 \mathrm{mEq}$ of sodium ; water excretion $236 \%$, and sodium $520 \%$ of the control days. This was $80 \%$ of the diuretic effect of a $2-\mathrm{ml}$. intramuscular injection of mersalyl B.P. in the same group of patients.

Compound S.C.2614 usually failed to produce a satisfactory diuresis in any other group of patients. There were 19 failures in 25 tests on 17 patients. No useful diuresis occurred in cardiac patients without pitting oedema, in patients with a low plasma sodium, a serum albumin below $2 \mathrm{~g}$. per $100 \mathrm{ml}$, , or a blood urea over $150 \mathrm{mg}$. per $100 \mathrm{ml}$.

There was not enough evidence to assess the effect of S.C.2614 in patients with renal disease, but there were a few. useful diuretic responses.

The high incidence $(23 \%)$ of gastro-intestinal disturbance provoked by S.C.2614 was regarded as a serious disadvantage, although such symptoms were usually mild.

Further studies are in progress with a related aminouracil compound which may prove to be less toxic than S.C.2614.

We gratefully acknowledge the help given by Professor M. L. Rosenheim and the physicians of University College Hospital; by the nursing staff, the normal test subjects; by Mr. G. T. Franglen, who did some of the earlier chemical estimations; and by Dr. Irwin C. Winter, of G. D. Searle and Co., for information and supplies of the aminouracil diuretics.

\section{REFERENCES}

Blumgart, H. L., Gilligan, D. R., Levy, R. C., Brown, M. G., and Volk, M. C. (1934). Arch. intern. Med., 54, 40

Evans, W., and Paxon, T. (1941). Brit. Heart J., 3, 112.

Kattus, A. Arrington, T. M., and Newman, E: V. (1952). Amer, J. Med., 12, 319

- Newman, E. V., and Franklin, J. (1951). Bull. Johns Hopk. Hosp., 89, 1.

Papesch, V., and Schroeder, E. F. (1950). Abstracts 117th Meeting of the American Chemical Society, Philadelphia.

Spencer, A. G., and Franglen, G. T. (1952). Lancet, 1, 190

Thomson, W. A. R. (1937). Quart. J. Med., n.s. 6, 321.

Since the publication of the Curtis Report (1946) and the carrying out of its recommendations for children "taken into care," increasing attention has been given to children neglected or ill-treated in their own homes. The National Association for Maternity and Child Welfare, in collaboration with other bodies, has issued a short report, Child Neglect and the Social Services, on the present position and future possibilities for dealing with child neglect or illtreatment in the home. It is estimated that the 80,000 problem families in England and Wales contain upwards of 250,000 children. A joint circular issued by the Home Office and the Ministries of Health and Education in 1950 drew attention to the powers of local authorities under the Children Act, the National Assistance Act, and the Education Acts. The circular suggested that officers should be designated to be responsible for enlisting the interest and cooperation of local services concerned with the welfare of children in their homes, that these officials should meet regularly officers of local authorities and other responsible organizations, and that cases of child neglect and ill-treatment should be reported to the designated officer. The report is obtainable from the National Association for Maternity and Child Welfare, at Tavistock House North. Tavistock Square, London, W.C.1, price 2 s. 